\title{
Evaluating barriers inhibiting investors participation in Public-Private Partnership project bidding process using structural equation model
}

\author{
R. A. Ojelabi , O. O. Oyeyipo , A. O. Afolabi \& I. O. Omuh
}

To cite this article: R. A. Ojelabi , O. O. Oyeyipo , A. O. Afolabi \& I. O. Omuh (2020): Evaluating barriers inhibiting investors participation in Public-Private Partnership project bidding process using structural equation model, International Journal of Construction Management, DOI: 10.1080/15623599.2020.1840010

To link to this article: https://doi.org/10.1080/15623599.2020.1840010

Published online: 03 Nov 2020.

Submit your article to this journal $\sqsubset$

Џ Article views: 47

Q View related articles $\sqsubset$

View Crossmark data $₫$ 


\title{
Evaluating barriers inhibiting investors participation in Public-Private Partnership project bidding process using structural equation model
}

\author{
R. A. Ojelabi ${ }^{\text {, }}$, O. O. Oyeyipo ${ }^{b}$, A. O. Afolabi ${ }^{a}$ and I. O. Omuh ${ }^{a}$ \\ ${ }^{\mathrm{a} D e p a r t m e n t}$ of Building Technology, Covenant University, Ota, Ogun, Nigeria; ${ }^{\mathrm{b}}$ Quantity Surveying Department, Bells University of Technology, \\ Ogun, Nigeria
}

\begin{abstract}
The study investigates the critical barriers restraining private investors from participating in the PPP construction project bidding process. Hence, three key potential inhibiting factors, which include political constraints, public sector poor PPP capacity, and undefined project scope, were investigated. Therefore, the study adopted a quantitative research technique through a questionnaire survey to obtain data from 384 PPP practitioners sample representative in Lagos and Abuja, Nigeria. The survey recorded 274 responses, and SmartPLS (v.3.2.3) was used for the data analysis. The study developed a conceptual model to formulate hypotheses which were validated with Smart PLS3. Findings from the study indicated that the three key factors have a significant effect on the private investor's decision not to participate in the PPP bidding process. The findings from this study can help the government understand how to attract investors under her PPP arrangement. The study is unique based on the research idea and approach.
\end{abstract}

\section{KEYWORDS}

Public-Private partnership; structural equation model; construction industry; Nigeria

\section{Introduction}

The construction industry is one of the key industries that engages in the production of public infrastructural facilities that are essential in economic development. The procurement of the basic socio-economic infrastructure are being facilitated by the industry players or stakeholders which includes governments, financial investors, contractors and consultants among others. However, under the traditional procurement system, the government's contributions in public infrastructural provision is massive compared to other industry players. Nevertheless, the government traditional role in public infrastructure procurement is becoming insignificant due to the geometric increase in infrastructural need in the global space (Babatunde et al. 2015; Ojelabi et al. 2019). Therefore, the world global agenda in the $21^{\text {st }}$ century has called for collaborations beyond a sector of an economy in the provision the basic infrastructure critical for human survival (Global Sustainable Development Report 2019). Hence, the Public-Private Partnership procurement system which allows for collaboration between the public and private sector for the provision public infrastructural was birthed. However, under the modern procurement arrangement, Public-Private Partnership (PPP), the financial investors' position is very crucial due to role they play in the procurement chain. Despite the government role in initiating the essential public infrastructural projects for PPP procurement application, the implementation of the procurement option is highly dependent on the financial investors. The key step to adopting PPP in public infrastructural provision with PPP procurement route lies in the investors' interest and desire to bid for the PPP construction project (ElMashaleh et al. 2014). Oyeyipo et al. (2019) further reiterated that investor's action in the preparation and submission of bids for construction project is the process through which a project can be acquired and executed. Therefore, the bidding phase in the implementation of PPP procurement route is highly strategic to the success of the procurement system in public infrastructure delivery. Unlike other procurements bidding approach, the PPP procurement bidding phase is one of the most complex due to the numbers of participants involve in the bidding process. Hence, there are challenges that are linked to the complexity of the PPP bidding process limiting investor's decision to bid for PPP construction projects. Therefore, it is critical to uncover the potential factors limiting investor's bidding decision for construction projects under the PPP arrangement. Several research work have been conducted on the factors affecting contactor bidding decision on construction projects (Shash 1993; Alsaedi et al. 2019; Oyeyipo et al. 2019). However, there is a dearth of study addressing the challenges confronting the financial investor's in the bidding process for PPP construction project. Therefore, this study focused on the research gap by identifying the potential inhibitors which include political constraints, undefined project scope and public sector poor PPP in the PPP bidding process. Hence, the inhibitors was used in developing a conceptual model to determine its potential impact on the investors bidding limitations. The model was developed using Smart-PLS (v3.2) by adapting the PPP bidding process inhibitors as exogenous latent construct and bidding process limitations as the endogenous latent construct.

The study was conducted in Lagos and Abuja, Nigeria. The research was beneficial to the PPP stakeholders and the research community at large as it enable PPP key stakeholders within the built environment in the study locations and beyond to understand the key challenges discouraging the private investor's interest in bidding for PPP public construction projects. Likewise, the 
study was useful to the research community as it add to the pool of knowledge on PPP research.

\section{Literature review}

The procurement of PPP construction projects unlike other projects passes through different phases, but the bidding phase is one of the key or strategic phase in PPP that determines the implementation of the procurement route and possible transitioning to the operational phase. The bidding phase in PPP construction project establishes the first phase of interaction between the governments and private investors in public infrastructure procurement. The bidding phase tends to reveal the level of commitment of the public sector to PPP and the intentions of the private sector investors in PPP project. However, the interactions of the parties at this phase of the PPP procurement option is highly dependent on the private investor's decision to bid for PPP construction projects. El-Mashaleh (2010) asserted that the bidding phase in a PPP project procurement is a crucial stage which is highly dependent on the investors. Ravanshadnia et al. (2011); Chua and $\mathrm{Li}$ (2000) opined that there are factors that determine the investors decision to bid for a PPP project. Over the years, some of these factors have contributed to the termination of PPP project procurement process at the bidding phase due to investor's decision not to bid. Due to the termination of PPP projects at this phase of the procurement process, there has been massive loss of investments that can guarantee provision of employment for the people, transfer of technology knowledge to the locals and enhances local economic development. Therefore, it is essential to examine related limiting factors influencing the private investor's decision not to bid for PPP projects and related theory establishing this study.

\section{Factors limiting investors bidding decision for PPP projects}

Unlike the existing procurement methods, the Public-Private Procurement system is highly complex and more capital intensive. The nature of PPP projects has propelled investors to evaluate the suitability of the PPP environment and project information related factors before any financial commitment and otherwise. Hence, some of the factors that relates to environment suitability and project information issues have the tendency to discourage private investors not to invest or bid for PPP projects. KPMG. (2010) carried out a study in Australia to evaluate some of the key challenges discouraging investors to participate in the country PPP market. The report from the study revealed that one of the key factors contributing to investor's decision not to bid for PPP project is due to the chunk of the bidding cost. The report further disclosed that the bidding cost for PPP projects in the country was found to be on the high side as it ranged from $0.5 \%$ to $1.2 \%$ of the total project cost. It was revealed that the high bidding cost is discouraging competition among investors for PPP projects within the Australian market and likewise acting as deterrent to new entrants into the PPP market. It is evident from the report that there is a fear of losing a bid by participants due to higher bidding cost; hence, discouraging participation in PPP related projects within the country. Also, KPMG report identify another key factor responsible for investor's lack of interest to bid for PPP project to be related to poor documentation of PPP project information. The study revealed that government lack of clarity on project requirements is causing bidders additional work or re-work throughout the bidding phase. The lack of clarity on PPP project information can send wrong signals to investors on the participating country diligence and readiness to implement PPP procurement for construction project delivery.

Similarly, Khaderi et al. (2019) identify lengthy bidding period as one the key issues limiting investor's decision to bid for PPP construction projects. The researchers revealed that the bidding process can take up to 22 Months before completion in the UK and 12-18 Months in Australia. Ahadzi and Bowles (2001) however emphasised that the implication of the lengthy time can leading increasing bidding cost. Though, Khaderi et al. (2019) stated that the lengthy bidding period could be avoided or mitigated by the public sector without compromising the value for money goal in PPP projects. HM Treasury (2006) further identified some of the issues attributed to the lengthy bidding process to include public sector poor management process, changes to project scope and design and provision of insufficient project information.

Beyond the issues identified as the factors discouraging investors under a PPP arrangement in some countries in the developed nations, World Bank et al. (2009) also reported some peculiar issues responsible for investors' reluctance to bidding for PPP construction project in developing nations especially in Africa. The report revealed that lack of comprehensive law supporting PPP implementation is one of the key factors discouraging investors from participating in PPP project bidding process in most countries in Africa. The investor's decision not to participate in a PPP environment that do not have established laws and regulations can be linked to their perception of a porous system that cannot guarantee their investment in any PPP project. Other issues identified in the report include bankability of the public sector obligations, fear of poor effectiveness and enforceability of PPP contract and related agreements and unreliable risk sharing among others. Similarly, World Bank Group and PPIAF (2016) disclosed that the rate of cancelation of past PPP construction projects is one of the major factor restraining investors from participating in PPP construction contract in the developing economies. It further accentuate that countries within the Sub-Saharan Africa region recorded the highest numbers of PPP construction project deal cancelation, and as a result, prospective investors are not willing to bid for PPP construction projects within the region. Likewise, United Nations Department of Public Information (2017) unveiled the perception of Infrastructure Concession for Africa (ICA), a group that promotes infrastructure development in Africa shared their view on why investors are not willing to engage in PPP construction deal within the continent. Among the factors identified include, lack of political will to support PPP projects in the region, uncertainty of the region PPP environment, lack of public institutions capacity in PPP affairs, weak regulatory framework and corruption. In the same vein, Sulser (2018) divulged that threat to investment resulting from economic instability is among the major factors preventing investors from considering partnering with government in the procurement public of infrastructure under a PPP arrangement in the developing world.

Also, there are other issues associated with the bidding phase of PPP procurement implementation in public construction project delivery. Hence, based on literature review, summary of issues associated with the PPP procurement bidding phase are documented and content analysis was performed on the variables identified by focusing and selecting specific codes of PPP bidding process barriers in categories as presented in Table 1. 
Table 1. PPP bidding process barriers.

\begin{tabular}{|c|c|c|}
\hline Code & PPP Bidding Phase Barriers & References \\
\hline & Political Constraints & \\
\hline PC1 & Political instability. & UNECE (2008); Gidado (2010) \\
\hline $\mathrm{PC2}$ & Political interference at the assessment and bidding phase. & Sader (2000); Gidado (2010) \\
\hline PC3 & Corruption in government. & Otairu et al. (2013); Schomaker (2020). \\
\hline PC4 & Lengthy delays due to political debate. & Akampurira et al. (2017); Chan, Lam, Chan, Cheung and Ke (2010). \\
\hline PC5 & Political reneging. & Akampurira, Root and Shakantu (2017) \\
\hline PC6 & Bureaucracy in PPP bidding process & Babatunde et al. (2015) \\
\hline PC7 & Lack of effective policy on PPP project bidding. & World Bank et al. (2009). \\
\hline PC8 & Poor commitment of government to PPP bidding system. & The World Bank et al. (2009). \\
\hline PC9 & Potential foreign exchange risks. & Gidado (2010); Akampurira et al. (2017). \\
\hline PC10 & Lack of government structure for effective decision making on PPP procurement process. & UNECE (2008); Gidado (2010). \\
\hline PC11 & Lack of approval for import waivers at the bidding phase. & Sy et al. (2016). \\
\hline PC12 & $\begin{array}{l}\text { Poor or weak legal backing on PPP procurement process. } \\
\text { Undefined Project Scope }\end{array}$ & The World Bank et al. (2009). \\
\hline UP1 & Lack of specifications and the quality of service. & Akintoye et al. (2003). \\
\hline UP2 & Lack of detailed project data by public sector. & Akintoye et al. (2003). \\
\hline UP3 & Abrupt change in project information. & Tien et al. (2016) \\
\hline UP4 & Perceived high risk due to unclear project data. & Rezouki and Hassan (2019) \\
\hline UP5 & Lack of project information memorandum. & The World Bank et al. (2009). \\
\hline UP6 & $\begin{array}{l}\text { Ambiguous project scope. } \\
\text { Poor PPP Capacity }\end{array}$ & Rezouki and Hassan (2019) \\
\hline PS1 & Public sector poor knowledge in managing PPP bidding process. & UNESCAP (2007) \\
\hline PS2 & Undue favoritism by public sector toward selected bidders. & Corbett and Smith (2006); Ahmed (2011). \\
\hline PS3 & The problem of administrative procedures and guidelines. & Gidado (2010); Yang et al. (2010). \\
\hline PS4 & Poor coordination between different public sector departments. & Lamech and Kazeem (2003); UNESCAP (2007). \\
\hline PS5 & Unfair allocation of project risk. & Rezouki and Hassan (2019) \\
\hline PS6 & Poor evaluation of bid documents by public sector. & Mahalingam (2010) \\
\hline PS7 & $\begin{array}{l}\text { Poor preparation of PPP project feasibility report. } \\
\text { Bidding process limitations }\end{array}$ & Public-Private Infrastructure Advisory Facility (2009). \\
\hline BP1 & High bidding cost. & KPMG. (2010); Rezouki and Hassan (2019). \\
\hline BP2 & Lengthy bidding period. & Khaderi et al. (2019). \\
\hline BP3 & Complex bidding process. & KPMG. (2010). \\
\hline BP4 & Non-competitive bidding. & Abdul-Aziz (2001); KPMG. (2010). \\
\hline BP5 & Poor system in handling bid documents. & The World Bank et al. (2009). \\
\hline BP6 & Poor feedback mechanism on bidding process. & The World Bank et al. (2009). \\
\hline BP7 & Lack of transparency in bidding process. & Asian Business (1996); Tien et al. (2016) \\
\hline
\end{tabular}

\section{Conceptual model}

In examining the challenges limiting the financial investor's participation at the bidding phase of PPP procurement implementation, PLS structural equation modelling was adopted and a model was developed. According to Vinzi et al. (2010), PLS-SEM modeling approach is regression based which adopt principal components factor analysis method in analyzing path models. David (2016) revealed that PLS path model consists of two arrays of equations which are inner model known as structural model and outer model known as measurement model. Rahman et al. (2013) disclosed that the relationships between the latent variables is define with the inner model while the outer model define the relationships between the latent variable and its observed indicators. Hence, the study used PLS-SEM in developing a model to better comprehend the determinant factors limiting financial investor's participation in bidding phase of PPP construction projects. The model was in two phases, the first phase consist of measurement model which quantify the relationships between the latent variables and their observed variables. Also, the second phase consist of structural model which specifies the relationships between the latent variables. The study adopted 32 observed variables from literature which are further classified in four groups which consists political constraints (12 variables), undefined project scope (6 variables) and public sector poor PPP capacity (7 variables) known as the exogenous latent variables and bidding process limitation (7 indicators) known as the endogenous latent variable. Hence, the exogenous and endogenous latent variables are used in developing the proposed conceptual framework. The conceptual model is shown in Figure 1
Hence, from the conceptual framework, the following hypotheses were proposed in the study.

H1- Political constraints has a significant limiting effect on the investor's participation at the bidding phase of PPP implementation in the procurement of public construction project.

H2- Public sector poor PPP capacity has a significant limiting effect on the investor's participation at the bidding phase of PPP implementation in the procurement of public construction project.

H3- Undefined project scope has a significant limiting effect on the investor's participation at the bidding phase of PPP implementation in the procurement of public construction.

\section{Research methods}

The study adopted quantitative research technique through a well-structured questionnaire survey in collecting data to test for the proposed hypotheses. The questionnaire survey was targeted at the PPP stakeholders in Lagos and Abuja, Nigeria. The targeted PPP stakeholders consists of concessionaires, contractors, consultants, government agents and financier with practical experience on PPP construction projects. However, due to the growing state of the PPP procurement system implementation in Nigeria, there is no documented list of PPP stakeholders operating in the country. Li et al. (2005) affirmed that when PPP is at the formative stage, the organisation and participants on PPP projects is increasing; therefore the population cannot be readily determined. Hence, in a bid to attain the sample representative of PPP stakeholders for the study, a project based method was 


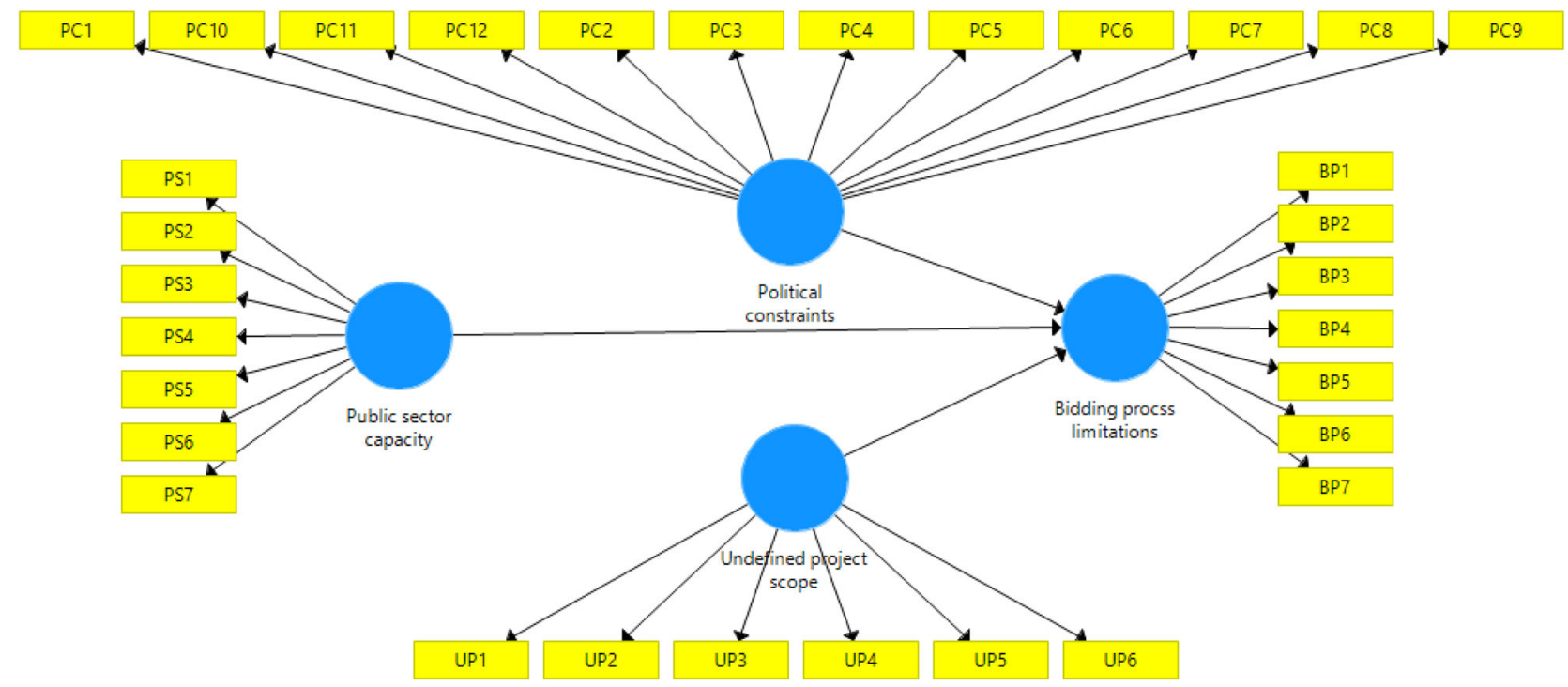

Figure 1. Initial conceptual model on PPP bidding process limitations.

Table 2. Breakdown of PPP stakeholders respondents.

\begin{tabular}{lllr}
\hline PPP Stakeholders & Lagos & Abuja & Total \\
\hline Public Sector Authorities (ministries, & 69 & 51 & 120 \\
$\quad$ agencies, departments and parastatals) & & & \\
Concessionaires & 21 & 11 & 32 \\
Financier & 11 & 5 & 16 \\
Contractors & 74 & 48 & 122 \\
Consultants & 56 & 38 & 94 \\
Total & $\mathbf{2 2 9}$ & $\mathbf{1 5 5}$ & $\mathbf{3 8 4}$ \\
\hline
\end{tabular}

adopted (Babatunde 2015). Through a purposive sampling technique, the study selected 19 PPP construction projects in Lagos and Abuja and 62 public-private firms were identified. Hence, 384 PPP stakeholders from the partnering organisations were identified and targeted as the study representative sample as shown in Table 2. Thus, with the support of four research assistants, the study questionnaire was distributed among the PPP stakeholders.

Prior to conducting the research, a pilot survey was carried out in a bid to establish the professionals' validity and suggestions on the constructs adopted in the study. From the pool of PPP stakeholders with practical experience on PPP projects, 30 PPP experts was selected for interview. The pilot survey was selfexecuted by engaging the PPP experts with the research questionnaire to solicit for their professional inputs. Therefore, suggestions gathered from the pilot survey was used in making the questionnaire better for the study.

The questionnaire was developed from 32 constructs from literature review which addressed the subject of interest and were further classified into four groups which include political constraints, undefined project scope, public sector poor PPP capacity and bidding process limitations. The questionnaire is structured into three sections. The first section addressed the letter of introduction which contain the basic objective and purpose of the study. The second section examined the respondent's characteristics, while the third section focused in measuring the PPP stakeholder's agreement on the barriers limiting investor's participation at the bidding phase with the Likert scale range 1 representing strongly disagree, to 5 representing strongly agree. The 32 constructs are categorised under four key groups, which three of the groups are exogenous latent construct and one is endogenous latent construct.

\section{Result presentation}

\section{Characteristics of respondents}

This section revealed the demographic information of the respondents as indicated in Table 3.

The Table 3 showed that $65 \%$ of the 274 participants in the study are from the private sector while the remaining $35 \%$ are from the public sector. Also, evidenced gathered from the Table 3 revealed the proportion of the respondents roles under a PPP arrangement in the study. The respondents representing contractor role has the highest participants in the study with $33.9 \%$ of the total respondents in the study. It was followed by the respondents representing the contracting role and government agents with $27.4 \%$ and $25.9 \%$ respectively. The least groups represented in the study are the concessionaire and financier groups with $9.1 \%$ and $3.7 \%$ respectively. The profession of the respondents within the built environment was also represented in in Table 3. The highest professional group in the study are the Architect with $28.1 \%$ and followed by the Builder group with $23.4 \%$ of the total sample representative in the study. The Quantity surveyor and Civil engineer groups represented in the study are very close with $20.4 \%$ and $20.8 \%$ respectively. The leas represented group in the study is the Estate surveyor group with $7.3 \%$ of the 274 professionals involved in the study. Also, the highest academic qualifications of the respondents in the study is equally captured in Table 3. The results showed that $61.3 \%$ of the total respondents have Master's Degree as their highest qualification and $33.2 \%$ are with Bachelor Degrees. Also, 2.9\% of respondents have $\mathrm{PhD}$ Degree as their highest academic qualification and $2.3 \%$ have Higher National Diploma at their highest qualification in the study. The results presented in Table 3 further showed the knowledge base of the respondents on PPP implementation for construction project delivery. The results revealed that $80.7 \%$ and $16.1 \%$ of the respondents have a good knowledge and very good knowledge base of PPP implementation process, while the remaining $3.2 \%$ of the respondents have average knowledge on PPP implementation process. It can be concluded from the preceding, that the respondents in the study are well characterized.

\section{Data analysis}

To simulate the data in the study in a bid to develop a model, PLS-SEM model tool was used. Hussain et al. (2018) described 
PLS-SEM models as path models that allow for multiple relationships testing among variables at once in a single model. Taylor and Geldenhuys (2019) further identified PLS-SEM model as a substitute to covariance-based structural equation modeling. Lin and Jeng (2017) uncovered the main applicability of the PLSSEM to include correlation structural models, regression models, and covariance models. Likewise, the researchers revealed that PLS-SEM is also used for path analysis, confirmatory factor

Table 3. Respondents characteristics.

\begin{tabular}{lcc}
\hline Characteristics & Frequency & Percentage \\
\hline Respondent Sector & 98 & \\
Public & 176 & 35.0 \\
Private & 274 & 65.0 \\
Total & & 100 \\
Respondent Role & 93 & \\
Contractor & 75 & 33.9 \\
Consultant & 71 & 27.4 \\
Government Agent & 25 & 25.9 \\
Concessionaire & 10 & 9.1 \\
Financier & 274 & 3.7 \\
Total & 77 & 100 \\
Respondent Profession & 56 & \\
Architect & 64 & 28.1 \\
Quantity Surveyor & 57 & 20.4 \\
Builder & 20 & 23.4 \\
Civil Engineer & 274 & 20.8 \\
Estate Manager & & 7.3 \\
Total & 7 & 100 \\
Highest Qualification & 91 & \\
HND & 168 & 2.6 \\
BSc/B.Tech/B.Eng & 8 & 33.2 \\
MSc/MPM/M.Tech & 444 & 61.3 \\
PhD & 221 & 2.9 \\
Total & 9 & 100 \\
PPP Knowledge Base & & \\
Very Good & & 16.1 \\
Good & 7.2 \\
Average & Total & 100 \\
\hline
\end{tabular}

analysis and second-order factor analysis. Henseler et al. (2009) highlighted that the implementation of PLS-SEM in developing a model is in two steps, which are measurement and structural model assessment. The researcher further disclosed that the measurement model assessment entails examining the reliability and ascertaining the consistence and validity of the variables used in developing the questionnaire for the study. Likewise, the researchers bolstered that the second-step of PLS-SEM which is the structural model assessment phase involved observing the predictive relevance $\left(\mathrm{Q}^{2}\right)$ of the model developed and the relationships between the concepts, assessing the significance of path coefficient and variance explanation of endogenous concepts $\left(\mathrm{R}^{2}\right)$ and effect size $\left(\mathrm{f}^{2}\right)$.

\section{Measurement model assessment}

The measurement model focused on computing the manifest variables consistency and validity. Hussain et al. (2018) revealed that the key standards in evaluating measurement model include composite reliability which is targeted at evaluating internal consistence, indicators outer loadings which is aimed at measuring individual indicator's reliability, average variance extracted (AVE) intended to estimate convergent reliability and FornellLarcker criterion and cross-loadings to assess discriminant validity. The consistence and validity of the constructs were attained by using Smart-PLS (v.3.2.3) (Ringle et al. 2015). The result generated from the analysis of the data is presented in Figure 2 and Tables 5-7.

Asgari (2016) opined that in determining the validity of the constructs measures, it is essential to ensure the suitability of the measures in the path model. Henseler et al. (2012) however bolstered that in defining the validity of constructs measures, indicators with low loadings below 0.7 should be eliminated as they have little explanatory power to the model. Memon and Rahman (2014) however indicated that outer loading with value of 0.7 and above is adjudged good. Hence, the result of the observed

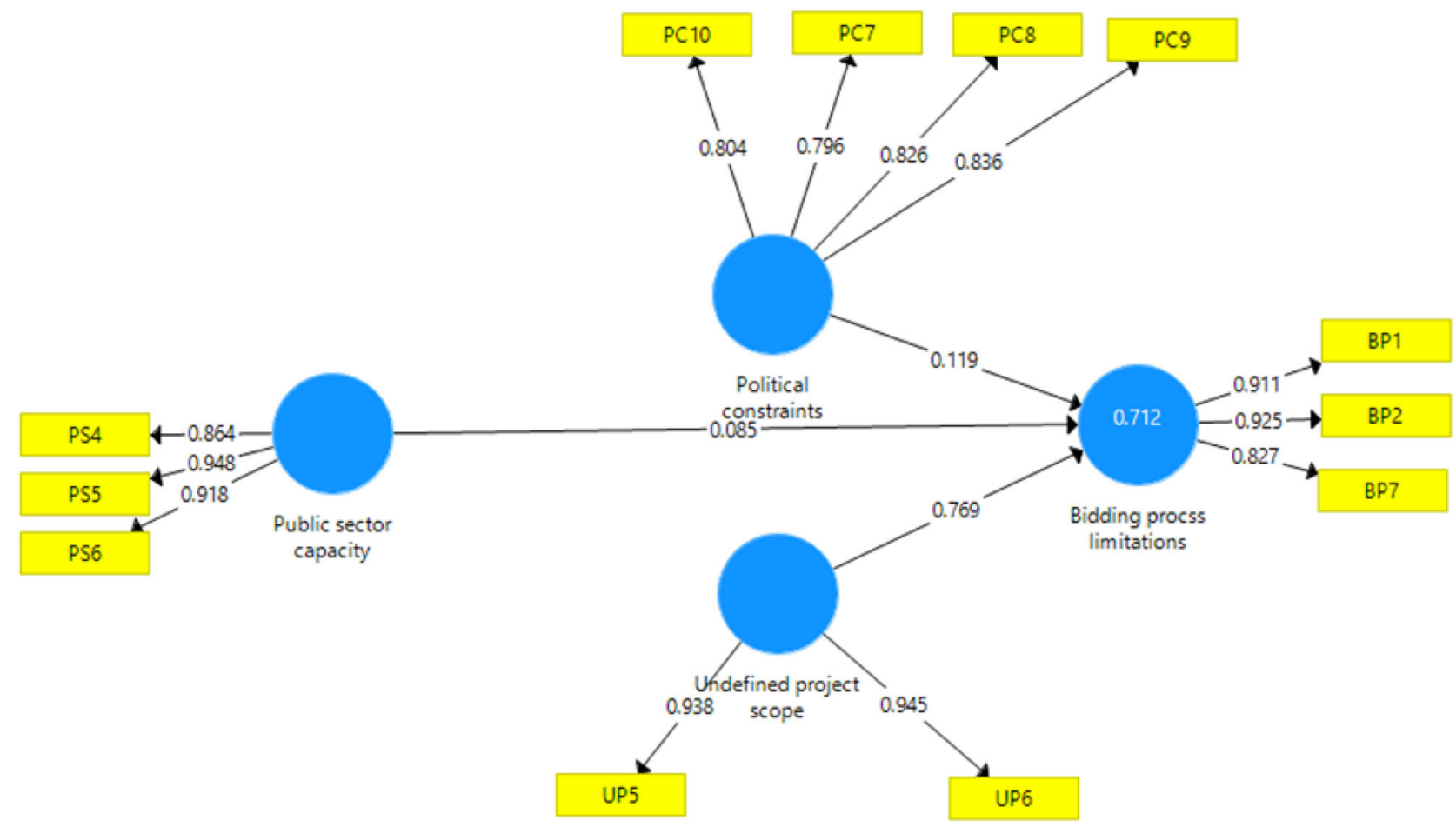

Figure 2. Final conceptual model on PPP bidding process limitation with PLS algorithm calculation. 
Table 4. Internal consistency, convergent validity, composite reliabity and AVE.

\begin{tabular}{|c|c|c|c|c|c|}
\hline Constructs & Indicators & Loadings & Cronbach's alpha & Composite Reliability & AVE \\
\hline \multirow[t]{4}{*}{ Bidding process limitations } & & & 0.867 & 0.918 & 0.790 \\
\hline & BP1 & 0.911 & & & \\
\hline & BP2 & 0.925 & & & \\
\hline & BP7 & 0.827 & & & \\
\hline \multirow[t]{5}{*}{ Political constraints } & & & 0.833 & 0.888 & 0.666 \\
\hline & PC10 & 0.804 & & & \\
\hline & PC7 & 0.796 & & & \\
\hline & PC8 & 0.826 & & & \\
\hline & PC9 & 0.836 & & & \\
\hline \multirow[t]{4}{*}{ Public sector capacity } & & & 0.897 & 0.936 & 0.829 \\
\hline & PS4 & 0.864 & & & \\
\hline & PS5 & 0.948 & & & \\
\hline & PS6 & 0.918 & & & \\
\hline \multirow[t]{3}{*}{ Undefined project scope } & & & 0.872 & 0.940 & 0.886 \\
\hline & UP5 & 0.938 & & & \\
\hline & UP6 & 0.945 & & & \\
\hline
\end{tabular}

Table 5. Fornell-Larcker criterion test.

\begin{tabular}{lcccc}
\hline & $\begin{array}{c}\text { Bidding } \\
\text { process } \\
\text { limitations }\end{array}$ & $\begin{array}{c}\text { Political } \\
\text { constraints }\end{array}$ & $\begin{array}{c}\text { Public } \\
\text { sector } \\
\text { capacity }\end{array}$ & $\begin{array}{c}\text { Undefined } \\
\text { project } \\
\text { scope }\end{array}$ \\
\hline Bidding process limitations & $\mathbf{0 . 8 8 9}$ & & & \\
Political constraints & 0.359 & $\mathbf{0 . 8 1 6}$ & & \\
Public sector capacity & 0.367 & 0.275 & $\mathbf{0 . 9 1 1}$ & \\
Undefined project scope & 0.830 & 0.282 & 0.324 & $\mathbf{0 . 9 4 1}$ \\
\hline
\end{tabular}

Table 6. Cross-loadings.

\begin{tabular}{lcccc}
\hline & $\begin{array}{c}\text { Bidding } \\
\text { process } \\
\text { limitations }\end{array}$ & $\begin{array}{c}\text { Political } \\
\text { constraints }\end{array}$ & $\begin{array}{c}\text { Public } \\
\text { sector } \\
\text { capacity }\end{array}$ & $\begin{array}{c}\text { Undefined } \\
\text { project } \\
\text { scope }\end{array}$ \\
\hline BP1 & $\mathbf{0 . 9 1 1}$ & 0.292 & 0.306 & 0.849 \\
BP2 & 0.925 & 0.338 & 0.381 & 0.742 \\
BP7 & 0.827 & 0.338 & 0.291 & 0.590 \\
PC10 & 0.296 & 0.804 & 0.146 & 0.258 \\
PC7 & 0.254 & 0.796 & 0.229 & 0.211 \\
PC8 & 0.294 & 0.826 & 0.245 & 0.239 \\
PC9 & 0.322 & 0.836 & 0.274 & 0.214 \\
PS4 & 0.276 & 0.170 & 0.864 & 0.299 \\
PS5 & 0.352 & 0.282 & 0.948 & 0.305 \\
PS6 & 0.364 & 0.282 & 0.918 & 0.285 \\
UP5 & 0.757 & 0.301 & 0.281 & 0.938 \\
UP6 & 0.804 & 0.233 & 0.328 & 0.945 \\
\hline
\end{tabular}

Table 7. Structural model assessment indicating path coefficients and T-statistics.

\begin{tabular}{llcccc}
\hline Hypothesis & Relationship & $\begin{array}{c}\text { Standardized } \\
\text { Beta }\end{array}$ & T-Statistics & P-value & Inference \\
\hline H1 & PC - > BP & 0.119 & 2.998 & 0.003 & Supported \\
H2 & PS $->$ BP & 0.085 & 2.129 & 0.034 & Supported \\
H3 & UP $->$ BP & 0.769 & 24.821 & 0.000 & Supported \\
\hline
\end{tabular}

variables reliabilities and convergent validities after exclusion of variables with loadings below 0.7 in the study is displayed in Figure 2.

Table 4 indicated factor loadings, Cronbach's alpha, composite reliability and AVE values in the study. George and Mallery (2003) opined that Cronbach's alpha value greater than or equal to 0.7 and Hock et al. (2010) mentioned that composite reliability value of 0.6 and above are adjudged good for the measurements of internal consistence in construct reliability. The Cronbach's alpha and composite reliability values indicated in Table 4 are above the threshold value, hence, the values attained in the study are acceptable for the construct reliability measurements. Hair and Lukas (2014) mentioned that the average variance explained (AVE) value for convergent and validity test should not be less than 0.5. Therefore, the AVE value in this study are good as they are above 0.5 for all the constructs.

The next test is to determine the discriminants validity of the latent constructs. Asgari (2016) asserted that discriminant validity is the degree of empirical difference in a construct from other constructs in the path model. The Fornell-Larcker criterion test in Table 5 and factors cross loadings in Table 6 in the study are used in determining the discriminants validity of the latent constructs. According to Fornell and Larcker (1981) criterion, an observed variable share more variance with its assigned indicators compared to any other observed variables. Shanmugapriya and Subramanian (2015) further disclosed that the AVE of each observed variable should be more than the observed variable's highest square correlation with any other variable in the model. The Fornell-Larcker criterion test result is presented in Table 5 in which the diagonal ire the square root of the AVE. From indication in the Table 5, the values across the diagonal meets the Fornell-Larcker assumption in determining the discriminants validity of the latent constructs. Likewise, the results of the factor cross loadings in Table 6 is also used to test for discriminant validity of the observed variables in the model, Chin (1998) asserted that the indicators relationship value with its observed variables must be higher than the value generated with other enablers relationship in the model. Therefore, the value of the relationship between the indicators and its observed variables in Table 6 are higher than values generated with other variable. Hence, it can be inferred that both results generated in Table 5 for FornellLarcker criterion test and Table 6 for factor cross-loadings both confirm the discriminant validity of the observed variable in the model.

\section{Structural model assessment}

After establishing the validity and reliability of the measurement model, the next step is to measure the structural model results. This entails investigating the model predictive abilities and the relationships between the latent variables. Hussain et al. (2018) unveiled that the following criteria which include the coefficient of determination $\left(\mathrm{R}^{2}\right)$, path coefficient $(\beta$ value) and T-statistics value, effect size $\left(\mathrm{f}^{2}\right)$ and the predictive relevance of the model $\left(\mathrm{Q}^{2}\right)$ are standards that enable the assessment of the structural model. Taylor and Geldenhuys (2019) revealed that the process in validating the explanatory capacity of the model is achieved through the bootstrapping procedure on Smart-PLS (v3.2.3). The bootstrapping process compute the significance of PLS coefficient though the resampling technique. Therefore, the study uses the 


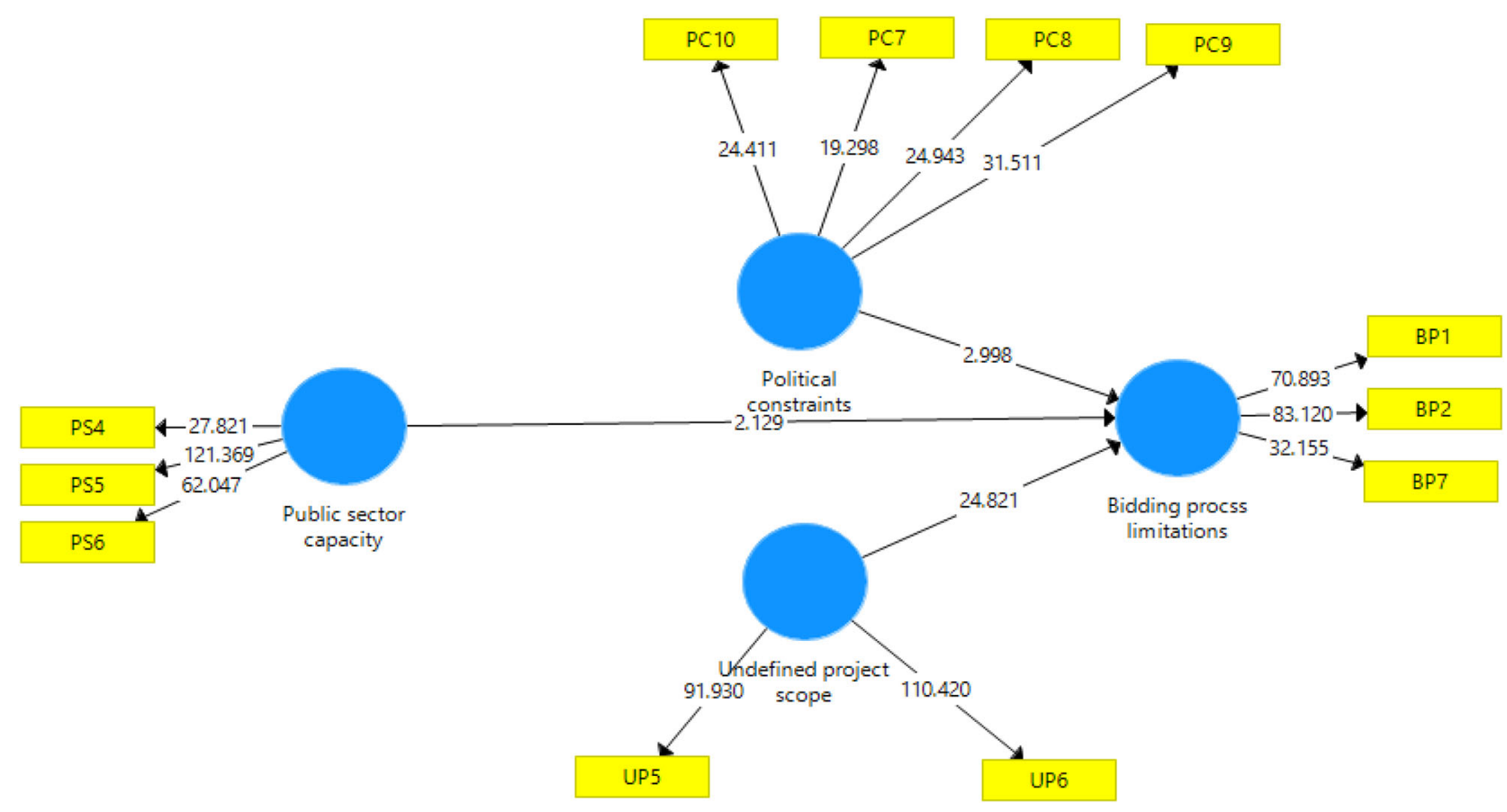

Figure 3. Structural model assessment using bootstrapping procedure.

Table 8. Effect size (f2).

\begin{tabular}{lllccc}
\hline Dependent Construct & Independent Construct & $\mathrm{R}^{2}$ (included) & $\mathrm{R}^{2}$ (excluded) & Effect size & Inference \\
\hline PPP Bidding limitations & Political constraints & 0.712 & 0.584 & 0.444 & Large \\
PPP Bidding limitations & Public sector poor PPP capacity & 0.712 & 0.596 & 0.403 & Large \\
PPP Bidding limitations & Undefined project scope & 0.712 & 0.651 & 0.211 & Moderate \\
\hline
\end{tabular}

bootstrapping procedure with 500 sample and 274 cases to determine the significance of the proposed hypothesis by considering the path coefficient and " $t$ " value. The result of the bootstrapping procedure generate the path model with the t-value in Figure 3 and the $\mathrm{p}$-Value indicated in Table 7.

In $\mathrm{H} 1$, the study proposed that political constraints has a significant limiting effect on the investor's participation at the bidding phase of PPP implementation in the procurement of public construction project. Evidence presented in Figure 3 and Table 7 showed that political constraints has a significant limiting effect on the investors participation at the bidding phase of PPP procurement route with $(\beta=0.119, \mathrm{~T}=2.998, p=0.003)$. Also, the second hypothesis $(\mathrm{H} 2)$ predicted that public sector poor PPP capacity has a significant limiting effect on the investor's participation at the bidding phase of PPP implementation in the procurement of public construction project. Hence, the hypothesis is supported because of the fact garnered from the result shown in Figure 3 and Table 7 with $(\beta=0.085, \mathrm{~T}=2.129, p=0.034)$. Furthermore, in the third hypothesis (H3), the study proposed that undefined project scope has a significant limiting effect on the private investor's participation at the bidding phase of PPP implementation in the procurement of public construction project. Hence, the path coefficient value in Figure 3 and the values shown in Table 7 supported the hypothesis with $(\beta=0.769$, $\mathrm{T}=24.821, p=0.000)$. From indication, the result presented for the hypotheses testing in the study, the T-value of the three relationships measuring the hypothesis proposed are all above 1.96 which is the threshold value beyond which significant relationship can be confirmed. However, the study further revealed the beta coefficient $(\beta)$ which determine the level of effect of each of the exogenous construct on the endogenous construct. The result presented in Table 7 showed that undefined project report has the strongest effect with $76.9 \%$ and followed by political constraints with $11.9 \%$ and the least among the three is public sector poor PPP capacity with $8.5 \%$ effect.

The predictive capacity of the structural model was also determined by calculating for $\mathrm{R}$ square value. The $\mathrm{R}$ square also known as coefficient of determination represents the proportion of the variance in the exogenous latent variable that can be explained by the exogenous latent variable in the model. Hair et al. (2013) the following value of $\mathrm{R}$ square $0.75,0.50$ and 0.26 are considered as substantial, moderate and weak respectively in determining the predictive capacity of the structural model. Hence, the $R^{2}$ is at 0.712 which signifies that by putting together all the exogenous have the tendency to effect $71.2 \%$ change in the endogenous variable (bidding process limitation).

Also, the effect size $\left(f^{2}\right)$ which measures the effect of the independent construct on the dependent construct in the model was calculated. The effect size $\left(f^{2}\right)$ is evaluated by observing the change in the dependent construct when there is an omission in the predictor which change the coefficient of determination $\mathrm{R}^{2}$. Chin (1998) proposed the given formula in calculating the effect size $\left(\mathrm{f}^{2}\right)$.

$$
\mathrm{f}^{2}=\mathrm{R}^{2} \text { included }-\mathrm{R}^{2} \text { excluded }
$$

$1-\mathrm{R}^{2}$ included

The result from the calculation of the effect size $\left(f^{2}\right)$ is presented in Table 8 . Cohen (1988) suggested that the effect size 
Table 9. Construct cross-validated redundancy (Q2).

\begin{tabular}{llll}
\hline & \multicolumn{1}{c}{ SSO } & \multicolumn{1}{c}{ SSE } & $\mathrm{Q}^{2}(=1-\mathrm{SSE} / \mathrm{SSO})$ \\
\hline Bidding process limitations & 825.000 & 374.386 & $\mathbf{0 . 5 4 6}$ \\
Political constraints & 1100.000 & 1100.000 & \\
Public sector capacity & 825.000 & 825.000 & \\
Undefined project scope & 550.000 & 550.000 & \\
\hline
\end{tabular}

Table 10. Model-fit.

\begin{tabular}{ll}
\hline & Estimated Model \\
\hline SRMR & 0.060 \\
d_ULS & 0.279 \\
d_G & 0.226 \\
Chi-Square & 380.972 \\
NFI & 0.824 \\
\hline
\end{tabular}

$\left(\mathrm{f}^{2}\right)$ is weak if the value is 0.002 , moderate if the value is 0.15 and strong if the value is 0.35 . Hence, the result presented in Table 8 showed that political constraints and public sector poor PPP capacity have large effect on the bidding process limitations, while undefined project scope has moderate effect on the dependent construct.

In addition, the model's predictive relevance $\left(Q^{2}\right)$ is also determined by initiating the blindfolding procedures and calculating the cross-validated redundancy. David (2016) revealed that the cross-validated redundancy measurement in $\mathrm{Q}^{2}$ statistics is identified as the most recommended blindfolding output among other cross-validated measures because it focus on the model fit of the PLS latent variable model. Hussain et al. (2018) unveiled that $\mathrm{Q}^{2}$ measure acclaimed that the conceptual model has the capacity to predict the endogenous latent construct and its value in measuring a specific endogenous construct must be greater than zero. Hence, the value of the $\mathrm{Q}^{2}$ in the model generated in this study is greater than zero as indicated in Table 9.

Also, the model fit criterion was assessed by determining the standardized root mean square (SRMS) index. Chen (2007) revealed that, the SRMS is an index of the average degree of the differences between the observed correlation and the hypothesized covariance matrices. $\mathrm{Hu}$ and Bentler (1998) however proposed that the when the SRMS value is $=<0.08$, then the model is certified good fit. Therefore, the result of on the SRMS index presented in Table 10, showed that the model is good fit because its value is 0.06 within the threshold value for good fit.

\section{Discussion of findings}

The purpose of the study was to reveal the key exogenous latent constructs limiting the private investor's participation at the bidding phase of PPP procurement option in the management of public construction projects using the PLS-SEM procedure. The key constructs examined in measuring the inhibitors discouraging investor's participation at the PPP procurement bidding phase include political constraints, undefined project scope and public sector poor PPP capacity. From the results presented in the study, political constraints has a significant effect on the private investors participation at the bidding phase of PPP procurement implementation with $(\beta=0.119, \mathrm{~T}=2.998, p=0.003)$. The results implies that the private investors decision not to participate at the bidding phase of PPP procurement option is been influenced by the political constraints experienced by the investors at this stage. ADB et al. (2005) affirmed the study by revealing that political constraints is a key inhibitors to the participation of investors at the bidding phase of PPP procurement route. The report further revealed that political agent's attitude which include interference in the procurement bidding process, unnecessary demands for benefits from investors and reneging on agreement among others are critical issues restraining investors participation in the PPP bidding phase.

Furthermore, the study findings on the effect of public sector poor PPP capacity on investors decision to participate at the bidding phase of PPP procurement option is also significant with $(\beta=0.085, \mathrm{~T}=2.129, p=0.034)$. The result shows that the poor capacity of public sector officials in the management of PPP bidding process contributed to the investor's fear to bidding for PPP project. Babatunde et al. (2015) also attested that deficiencies in public sector capacity in PPP bidding arrangement can limit her chances in attracting investment to her PPP market.

Also, the study unveiled that undefined project scope equally have a significant effect on the private investor's decision to participate in PPP bidding process with $(\beta=0.769, \mathrm{~T}=24.821$, $p=0.000)$. Evidence gathered from the result showed that the exogenous latent construct has the highest effect on the investor's lack of participation at the PPP bidding phase for construction project with $76.9 \%$ contribution. Tien et al. (2016) also agreed that poor project scope is key inhibitor to PPP investors decision not to bid for PPP projects due to risk that are attributed to it.

\section{Conclusion and recommendation}

The objective of the study was to unveil the issues restricting investors from participating for PPP construction project in Nigeria. The study used structural equation model approach to measure the significance factors discouraging investors from participating in PPP construction projects in Nigeria. Hence, the study provide compelling evidence on the critical inhibitors discouraging private investor's participation in bidding for PPP construction project through hypotheses testing on three key factors. The first inhibiting factor established as a key influence on the private investor's decision not to participate in PPP bidding phase for construction project procurement is due to political constraints in the bidding process. Some of the issues are attributed to the political constraints are due to lack of effective policy on PPP project bidding, poor commitment of the government to PPP bidding system, potential foreign exchange risks and lack of government structure for effective decision making on PPP procurement process.

Another key factor discovered from the study restraining the private investor's from participating in the PPP bidding process is due to public sector poor PPP capacity. The public sector poor capacity in PPP bidding process are due to the problem of administrative procedure and guidelines, poor coordination between different public sector departments, unfair allocation of project risk and poor evaluation of bid documents by public sector.

Finally, undefined project scope was also discovered as an inhibiting factor to private investor's participation in PPP bidding process. The factor has the highest restraining effect on the investor's decision to participate in the bidding process for PPP construction project. The undefined project scope are mainly due to lack of project information memorandum and ambiguous project scope

The three key inhibiting factors identified in the study have a collective effect in limiting investor's from participating in the PPP bidding process for construction project procurement. Hence, the study recommended that to attract private investors 
to participating in the PPP bidding process, the fundamental issues identified in this study as the contributing factors restraining the investors have to be addressed by the government.

\section{Acknowledgments}

The researchers acknowledged the assistance of Covenant University through the Covenant University Center for Research, Innovation and Development for the support to carry out the research.

\section{Disclosure statement}

The authors declare that they have no known competing financial interests or personal relationships which have, or could perceived to have, influenced the work reported in this article.

\section{References}

Abdul-Aziz A. 2001. Unraveling of BOT scheme: Malaysia's indah water consortium. J. Constr. Eng. Manage. 127(6):457-460.

ADB, JBIC, and World Bank. 2005. Connecting East Asia: a new framework for infrastructure. Washington, DC: ADB, JBIC, and World Bank, Manila, Tokyo.

Ahadzi M, Bowles G. 2001. The private finance initiative: the procurement process in perspective. Proceedings of the 17th Annual Conference of ARCOM; Sep; Salford, p. 2-5.

Ahmed M. 2011. PPP for infrastructure development: The Nigerian experience. [accessed 2015 Aug 22]. Available from: www.icrc.gov.ng/wpcontent.

Akampurira E, Root D, Shakantu W. 2017. Stakeholder perceptions in the factors constraining the development and implementation of Public Private Partnerships in the Ugandan electricity sector. J. Energy South. Afr. 20(2):2-9.

Akintoye A, Hardcastle C, Beck M, Chinyio E, Asenova D. 2003. Achieving best value in private finance initiative project procurement. Constr Manage Econ. 21(5):461-470.

Alsaedi M, Assaf F, Hassanain MA, Abdallah A. 2019. Factor affecting contractors' bidding decisions for construction projects in Saudi Arabia. Buildings. 9(2):33.

Asgari A. 2016. Introduction to structural equation modeling partial least squares (SEM-PLS). [accessed 2019 Sep 20]. Available from: https://www. slideshare.net/pallobby/introduction-to-structural-equation-modeling-partial-least-sqaures-sempls-61043221.

Asian Business. 1996. Special report on Asia's infrastructure boom. Asian Business. p. 60-69.

Babatunde S. 2015. Developing Public-Private Partnership strategy for infrastructure delivery in Nigeria [doctoral thesis]. Newcastle upon Tyne, UK: Northumbria University.

Babatunde SO, Perera S, Zhou L, Udeaja C. 2015. Barriers to Public Private Partnership projects in developing countries: a case of Nigeria. Eng Const Arch Man. 22(6):669-691.

Chen FF. 2007. Sensitivity of goodness of fit indexes to lack of measurement invariance. Struct Equation Model. 14(3):464-504.

Chin WW. 1998. The partial least squares approach to structural equation modeling. Mahwah, NJ: Lawrence Erlbaum Associates.

Chua DKH, Li D. 2000. Key factors in bid reasoning model. J Constr Eng Manage. 126:46-57.

Cohen J. 1988. Statistical power analysis for the behavioural sciences. New Jersey: Lawrence Erlbaum Associates Hillsdale.

Corbett P, Smith R. 2006. An analysis of the success of the Private Finance Initiative (PFI) as the governments preferred procurement route. Proceedings Accelerating Excellence in the Built Environment Conference; Oct 2-4. Birmingham.

David G. 2016. Partial least squares (PLS-SEM). Asheboro, NC: Garson and Statistical Associates Publishing.

El-Mashaleh MS. 2010. Decision to bid or not to bid: a data envelopment analysis approach. Can J Civil Eng. 37(1):37-44.

El-Mashaleh MS, Al-Jundi A, Mattar S, Ali RA, Al-Hammad J. 2014. Understanding key bidding factors considered by top Jordan contractors. Jordan J Civ Eng. 8(4):455-464.

Fornell C, Larcker DF. 1981. Evaluating structural equation models with unobservable variables and measurement error. J Market Res. 18(1):39-50.
George D, Mallery M. 2003. Using SPSS for Windows step by step: a simple guide and reference. Boston (MA): Allyn \& Bacon.

Gidado K. 2010. PFI implementation and evaluation model for developing economics: example of Nigeria. Proceeding of the 2010 International Conference on Engineering, Project, and Production Management; October; Pingtung, Taiwan: National Pingtung University of Science and Technology. p. 14-15. Available from: www.ppml.url.tw/EPPM/conference/2010.

Global Sustainable Development Report. 2019. The future is now in science for achieving sustainable development. [accessed 2020 March 7]. Available from: https://sustainabledevelopment.un.org/content/documents/ 24797GSDR_report_2019.pdf.

Hair JF, Lukas B. 2014. Marketing research. Sydney (Australia): McGraw-Hill Education.

Hair JF, Ringle CM, Sarstedt M. 2013. Partial least squares structural equation modeling: rigorous applications, better results and higher acceptance. Long Range Plan. 46(1-2):1-12.

Henseler J, Ringle CM, Sinkovics R. 2009. The use of partial least squares path modeling in international marketing. Adv Int Market. 20:277-319.

Henseler J, Ringle CM, Sarstedt M. 2012. Using partial least squares path modeling in advertising research: basic concepts and recent issues. In: Okazaki S, editor. Handbook of research on international advertising. UK: Edward Elgar Publishing; p. 252-276.

HM Treasury. 2006. PFI: strengthening long-term partnerships. London: HMSO. [accessed 2019 Dec 10]. Available from: http://www.hm-treaury. gov.uk/media/IEI/33/bud06_pfi_618.pdf.

Hock C, Ringle CM, Sarstedt M. 2010. Management of multi-purpose stadiums: Importance and performance measurement of service interfaces. Int J Serv Technol Manage. 14(2-3):188-207.

Hu L, Bentler PM. 1998. Fit indices in covariance structure modeling: sensitivity to underparameterized model misspecification. Psychol. Methods. 3(4):424-453.

Hussain S, Fangwei Z, Siddiqi A, Ali Z, Shabbir M. 2018. Structural equation model for evaluating factors affecting quality of social infrastructure projects. Sustainability. 10(5):1415-1425. (

Khaderi SS, Abd Shukor AS, Bakri AS, Mahbub R. 2019. Public infrastructure project tendering through Public Private Partnerships (PPP) - a literature review. In: MATEC Web of Conferences. I 20182661026601015.

KPMG. 2010. PPP procurement review of barriers to completion and efficiency in the procurement of PPP projects. [accessed 2017 Apr 20]. Available from: www.kpmg.com/NZ/en/issuesAndInsights/ Articlespublications/SmarterProcurement/Documents/Review-of-barriersto-competition.pdf.

Lamech R, Kazim S. 2003. What International investors look for when investing in developing countries: results from a survey of international investors in the power sector, energy and mineral sector board. Discussion paper No. 06 the World Bank: Energy and Mining Sector Board.

Li B, Akintoye A, Edwards PJ, Hardcastle C. 2005. Perceptions of positive and negative factors influencing the attractiveness of PPP/PFI procurement for construction projects in the UK: findings from a questionnaire survey. Eng, Const Arch Man. 12(2):125-148.

Lin CL, Jeng CH. 2017. Exploring interface problems in Taiwan's construction projects using structural equation modeling. Sustainability. 9(5):822.

Mahalingam A. 2010. PPP experiences in Indian cities: barriers, enablers and the way forward. J. Constr. Eng. Manage. 136(4):419-429.

Memon AH, Rahman IA. 2014. SEM-PLS analysis of inhibiting factors of cost performance for large construction projects in Malaysia: perspective of clients and consultants. Sci World J. 2014:1-9.

Ojelabi RA, Fagbenle OI, Amusan LM, Afolabi AO. 2019. Government role in public-private partnership procurement of infrastructures: theoretical approach. 10th International Structural Engineering and Construction Conference; 20-25 May; Chicago, IL.

Otairu A, Umar AA, Zawawi NAW, Sodingi M, Hammad DB. 2013. Slow adoption of PPPs in developing countries: survey of Nigerian construction professionals. Paper Presented at 4th International Symposium on Infrastructure Engineering in Developing Countries. Procedia Engineering. Vol. 77; p. 188-195.

Oyeyipo OO, Odusami KT, Ojelabi RA, Afolabi AO. 2016. Factors affecting contractors' bidding decision for construction projects in Nigeria. J Constr Dev Countries. 21 (2):21-35.

Public-Private Infrastructure Advisory Facility. (2009). Toolkits for PublicPrivate Partnerships in roads and highways. [accessed 2020 May 29]. Available from: https://ppiaf.org/sites/ppiaf.org/files/documents/toolkits/ highwaystoolkit/6/pdf-version/5-31.pdf.

Rahman IA, Memon AH, Karim AT. 2013. Examining factors affecting budget overrun of construction projects undertaken through management procurement method using PLS-SEM approach. Evaluation of Learning 
for Performance Improvement International Conference; Feb 25-26; Malaysia.

Ravanshadnia M, Rajaie H, Abbasian HRA. 2011. Comprehensive bid/no-bid decision making framework for construction companies. Iran J Sci Technol Trans Civ Eng. 35:95-103.

Rezouki SE, Hassan JK. 2019. An evaluation of barriers obstructing the applicability of Public Private Partnership (PPP) in infrastructure development. Civ Eng J. 5(12):2643-2664.

Ringle CM, Wende S, Becker J-M. 2015. SmartPLS 3. Boenningstedt: SmartPLS GmbH. Available from: http://www.smartpls.com.

Sader F. 2000. Attracting foreign direct investment into infrastructure. [accessed 2019 Aug 10]. Available from: www.wbginvestmentclimate.org/ uploads/2974400181821314602140Attracting0FDI.PDF.

Schomaker RM. 2020. Conceptualizing corruption in Public Private Partnerships. Public Organiz Rev. doi:10.1007/s11115-020-00473-6.

Shanmugapriya S, Subramanian K. 2015. Structural equation model to investigate the factors influencing quality performance in Indian construction projects. Sadhana. 40 (6):1975-1987.

Shash AA. 1993. Factors considered in tendering decisions by top UK contractors. Constr Manage Econ. 11(2):111-118.

Sulser PO. 2018. Infrastructure PPP in the most challenging developing countries: closing the gap. [accessed 2020 Sep 16]. Available from: https:// www.iflr.com/pdfs/IFC-Book-May-17-2018.pdf.

Sy DT, Likhitruangslip V, Onishi M, Nguyen PT. 2016. Different perceptions of concerns factors for strategic investment of the private sector PublicPrivate Partnership transportation project. ASEAN J Sci Technol Dev. 5(2):5-25.

Tien SD, Veerasak L, Masamitsu O, Thanh NP. 2016. Impacts of risk factors on the performance of public-private partnership transportation projects in Vietnam. [accessed 2020 Oct 27]. Available from: https://mpra.ub.unimuenchen.de/96583/1/MPRA_paper_96583.pdf.
Taylor T, Geldenhuys S. 2019. Using Partial Least Squares to measure tourism students' satisfaction with work-integrated learning. South Africa: IntechOpen Publishing.

United Nations Department of Public Information. 2017. Partnerships giving Africa a new look. [accessed 2020 Sep 16]. Available from: https://www. un.org/africarenewal/sites/www.un.org.africarenewal/files/Africa_Renewal_ EN_August_November_2017.pdf.

United Nations Economic and Social Commission for Asia and the Pacific (UNESCAP). 2007. Public-Private Partnerships for infrastructure development: an introduction to issues from different perspectives. The high-level expert group meeting jointly organized by UNESCAP and the Ministry of Planning and Budget; Oct 2-4; Seoul.

United Nations Economic Commission for Europe. 2008. Guide book on promoting good governance in Public Private Partnerships. [assessed 2019 Jul 28]. Available from: www.unece.org/fileadmin/DAM/ceci/publications/ PPP.pdf.

Vinzi VE, Trinchera L, Amato S. 2010. PLS path modeling: from foundations to recent developments and open issues for model assessment and improvement. In: Esposito Vinzi V, editors. Handbook of partial least squares; Springer Handbooks of Computational Statistics. Springer-Verlag Berlin Heidelberg; p. 47-82.

World Bank Group and PPIAF. 2016. The state of PPPs: infrastructure Public-Private Partnerships in Emerging Markets \& Developing Economies 1991-2015. [accessed 2020 Sep 16]. Available from: https:// ppiaf.org/documents/3551/download

World Bank, ICA, and PPIAF. 2009. Attracting investors to African Public Private Partnerships. [accessed 2019 May 25]. Available from: https:// openknowledge.worldbank.org/handle/10986/2588.

Yang JB, Yang CC, Kao CK. 2010. Evaluating schedule delay causes for private participating public construction works under the build-operatetransfer model. Int J Project Manage. 28(6):569-579. 